\title{
PLURALISM RECONSTRUCTION IN FIQH STUDIES
}

\author{
Kusnan \\ wongedan.kk@gmail.com \\ STIT Syaichona Cholil Balikpapan
}

\begin{abstract}
Pluralism in religious studies is often placed in context and theological significance. As a result of this understanding, the understanding of the theological concepts in all religions led to the prohibition by MUI. While in some circles it provides an understanding of pluralism, in a religious context, from the point of view of its social function, which is a system of life that binds people in units or social groups. Pluralism is not an understanding that says all religions are the same. Pluralism must be separated from relativism and syncretism. In order to lead to a practical order in pluralist social fiqh, courage is required in deconstructing fiqh openly. In the fiqh of pluralism the construction that must be built is to understand plurality as a fact of sausageal where, each individual and group to know and understand each other. So it is necessary to restore universal values such as common benefit, egaliterianism, rationalism, pluralism as the principles of paradigmatic fiqh so as not to get caught up in the wedges of litreralism, fundamentalism, authoritarianism and conservatism
\end{abstract}

Keyword: Diversity, Concept and Studies

\section{INTRODUCTION}

Plurality or diversity is basically something that is inevitable and has been realized by all parties. But sometimes this diversity is not addressed wisely so it causes a social conflict. If this diversity is addressed wisely, it will become a treasure in enriching knowledge and thinking wisely as well.

In the view of Islam, the diversity is as a necessity so the emphasis in teaching is to understand one another with each other, if in the language of the Qur'an is ta'arafu. As QS. Al-Hujurat: verse 13

"O mankind, indeed $W$ e have created you from male and female and made you peoples and tribes that you may know one another. Indeed, the most noble of you in the sight 
IJIERM: Vol. 2 No. 1 Januari - April 2020

of Allah is the most righteous of you. Indeed, Allah is Knowing and Acquainted". (AlHujurat: 13).

The need for awareness of diversity in each individual who adheres to the teachings of Islam is still less massive. As an indication of this lack of massive awareness is the frequent occurrence of social conflict.

As a social fact, plurality is essentially the reality of one's own life, which cannot be avoided and denied. Because plurality is a sunatullah, so the existence must be recognized by every human being. However, this recognition in the level of reality is not yet fully in line with theoretical recognition and obstacles are still often encountered in the reality.

In daily life before being interfered with ideological, economic, sociopolitical, religious and other interests, humans live a life of a plurality in a scientific manner, without so much considering up to the level of "at least" the reality of plurality which is unified in everyday life. When humans with various interests (organization, politics, religion, culture and others) begin to elevate plurality issues at the peak of their consciousness and make it as the focus of attention. So the plurality which was originally normal, naturally changes into a very important thing. ${ }^{1}$

With the regard to the emergence of pluralism, especially religious pluralism, in recent years, the discourse on religious pluralism has become an important theme that has received a lot of attention from a number of Muslim scholars and at the same time seems to also raise pros and cons among thinkers, scholars and religious leaders. Moreover, when the MUI in the $7^{\text {th }}$ National Conference in July 2005 in Jakarta forbade religious pluralism, this issue had surfaced and had adorned the pages of the print and electronic media. When examined, then this difference seems to be related to the term pluralism of religions, cultures, differences in understanding the signs of the Qur'an verses about plurality and about claims of truth in a religion.

Considering the importance of the issue of understanding of religiouscultural pluralism, this paper tries to describe the terms of religious pluralism, the history of the idea of the birth of religious pluralism, how religious pluralism is viewed from the point of view of Islam, concerns about religious pluralism understanding following the MUI fatwa on religious pluralism understanding, and the issue of argumentation about religious pluralism, and

1 Saifuddin, Upaya Mempertemukan Realitas dalam Pluralitas Sosial Budaya, Jurnal Suhuf, No.01 Tahun XII, 2000, p.70 
the presentation on the arguments about religious pluralism as well as the author's views on religious pluralism.

\section{Terms About Understanding Religious Pluralism}

Etymologically, religious pluralism, comes from two words, namely "pluralism "and" religion ". Pluralism means" jama "'or more than one. In Arabic it is translated "al-ta'addudiyyah al-diniyyab". ${ }^{2}$ and in English "religious pluralism". Because the term religious pluralism comes from English, then to define it accurately must refer to the dictionary of the language. Pluralism in English according to Anis Malik Thoha, has three meanings: First, church understanding: (i) designation for people who hold more than one position in the church structure, (ii) holds two or more positions simultaneously, both church and non-church. Second, philosophical understanding; means a system of thought that recognizes the basis of thought that bases more than one. While the third, socio-political understanding: is a system that recognizes the coexistence of diversity of groups, whether racial, ethnic, sectarian or party style while still upholding aspects of differences that are very characteristic among these groups. ${ }^{3}$

As for religion, the sociologists and anthropologists tend to define religion from from the point of its social function- that is, a system of life that binds people together in social units or groups. Whereas, most theologians,

2 Terminologi pluralisme atau dalam bahasa Arabnya, "al-ta'addudiyyah",tidak dikenal secara popular dan tidak banyak dipakai dikalangan Islam kecualisejak kurang lebih dua dekade terakhir abad ke 20 yang lalu, yaitu ketika terjadiperkembangan penting dalam kebijakan internasional Barat yang baru yangmemasuki sebuah pase yang dijuluki Muhammad Imarah sebagai "marhalat alijtiyaah"(fase pembinasaan). Yaitu sebuah perkembangan yang prinsipnya terguratdan tergambar jelas dalam upaya Barat yang habishabisan guna menjajakanideology modernnya yang daingap universal, seperti demokrasi, pluralisme, HAMdan pasar bebas dan mengekspornya untuk konsumsi luar guna berbagaikepentingan yang beragam. Lihat : Anis Malik Thoha, Tren Pluralisme Agama,Tinjauan Kritis, Jakarta: Perspektif, 2005, p.180.

${ }^{3}$ Pluralism comes from the word "plural" which means a lot or number or "form of word used with reference to more than one" Pluralism in philosophy is a view which sees the world as composed of many creatures. This term is often opposed to monotheism which emphasizes unity in many ways or dualism which sees the world as consisting of two different things. 4 Monoism is divided into physica monoism which is manifested in the philosophy of materialism that all nature is an object and mental monoism or idealism which states that nature is entirely an idea or idea. In dualism, everything is seen as two. Zoroaster's philosophy, for example, saw Lithuania divided into darkness and light, and Descartes contrasted thoughts (mind) and matter (mater). In Pluralism, everything is seen as a lot. See : A.S. Hornby et.al., The Advanced Learner's Dictionary of Current English (Oxfort : Oxford UniversityPress, 1972), p. 744 in Riyal Ka'bah, Nilai-Nilai Pluralisme Dalam Islam,Bingkai gagasan yang berserak, (Ed.) Suruin, Bandung: Penerbit Nuansa, 2005, p.68. 
IJIERM: Vol. 2 No. 1 Januari - April 2020

phenomenologists and history of religion see religion from the very basic aspects of its substance - that is, something sacred. ${ }^{4}$

From the definition above, it can be drawn an understanding that "religious plurality" is a condition of coexistence between religions (in the broadest sense) that varies in one community while maintaining the specific characteristics or teachings of each religion.

But in terms of context in which "religious plurlism" is often used in studies and socio-scientific discourse on this modern era, has a different definition. John Hick, quoted by Malik Thoha for example states: religious pluralism is an idea that the world's major religions are different perceptions and conceptions about, and coincidentally represent, the real or supreme response from within various human cultural institutions, and that the transformation of the human form from self-centering to ultimate concentration takes place in real terms in each of these human cultural institutions and occurs, to the extent possible observed, to the same extent ". ${ }^{5}$ In other words, according to Anis, Hick stressed that all religions are actually manifestations of one reality. Thus, all religions are the same and nothing is better than the others.

The Indonesian Ulema Council defines Religious Pluralism as: "Religious Pluralism is an understanding that teaches that all religions are the same and therefore the truth of every religion is relative; therefore, every religious follower may not claim that only his religion is true while other religions are wrong. Pluralism also teaches that all religious believers will enter and coexist in heaven ".6

\section{The History of Religious Pluralism Idea}

To consider religious pluralism, it is necessary to trace its history, at least since the beginning of the $20^{\text {th }}$ century. At that time a German Christian theologian named Ernest Troeltsch revealed the need to invite pluralism amid the growing internal conflicts between Christians and between religions. In his article entitled "The Place of Christianity Among the Word Religions", he stated, The Christians have no right to claim the truest themselves. ${ }^{7}$ The same

\footnotetext{
${ }^{4} I b i d .$, p. 12-14.

${ }^{5}$ Anis Malik Thoha, Tren Pluralisme Agama, Tinjanan Kritis, Jakarta: Perspektif, 2005, p. 15

6 See Fatwa MUI in Media Dakwah Magazine No. 358 Ed. Sya'ban 1426H/September 2005, p. 49

7 The understanding religious pluralism according to Frans Magnis Suseno, in his book "Menjadi Saksi Kristus di Tengah Masyarakat Majemuk", Jakarta: Obor, 2004 quoted by
} 
opinions are expressed by Christian thinkers and theologians, such as William E. Hocking and famous historian Arnpl Toynbee. Therefore, this movement can be claimed as "Christian liberalization" which has been initiated and refined by Liberal liberal Friedrich Schleiremacher in the middle of the $19^{\text {th }}$ century. Its movements are called "Liberal Protestants".

The great internal Christian conflicts that were compiled were to encourage the US President, Grover Cleveland, to intervene the war between the sects. In the early 20th century, various Christian fundamentalists began to emerge in the United States. So in addition to conflicts between Christian sects, it turns out that political factors are also very closely related to the background of this idea. ${ }^{8}$

According to Anis Malik Thoha, the discourse of pluralism was born from the understanding of "liberalism". So it is not strange if the ideas of religious pluralism itself emerge and present in the packaging of "political pluralism" political liberalism. "Obviously, the idea of" liberalism "is no more a political response to the social conditions of a plural European Christian society with a diversity of sects, groups and schools. this sort of thing has always been limited in European Christian societies for a long time, then in the $20^{\text {th }}$ century it expanded to include other communities in the world.

\section{The Understanding of Fiqih Which is Pro Pluralism}

The meaning of fiqih according to the language is "understand". As in the verses of the Qur'an Hud verse 91 Allah SW'T says:

"They said: "O Shu'aib! we do not understand much of what you say and most surely we see you to be weak among us, and were it not for your family we would surely stone you, and you are not mighty against us".

In the Qur'an an-Nisa verse 78:

Wherever you are, death will overtake you, though you are in lofty towers, and if a benefit comes to them, they say: This is from Allah; and if a misfortune befalls them, they say: This is from you. Say: All is from Allah, but what is the matter with these people that they do not make approach to understand what is told (them)?

\footnotetext{
Adian Husaini Rejected by the Catholic church. On 2001, Vatican publishes an explanation "Dominus Yesus". In this explanation aside from rejecting the understanding of religious pluralism, it also reaffirms that Jesus Christ is the only introduction to Divine salvation and no one can go to you except Jesus. See the writings of Adian Husaini " Islam Liberal Paska Fatwa MUI, dalam majalah Media Dakwah, Edisi No. 358 Sya'ban 1426 H-September 2005, p.47.

8 Anas Malik Toha, Op.Cit., p. 50.
} 
IJIERM: Vol. 2 No. 1 Januari - April 2020

The two verses above mention the word "fiqih" as a meaning of understanding; or try to understand, or give understanding. Fiqih according to the Arabs is understanding and knowledge. After Islam came, the name of fiqih was used for religious knowledge because of its level of glory compared to other sciences. If we find the term of fiqih in the first generation of Islam then what is meant is religious knowledge. The religious knowledge referred to at that time was the science which was related to al-Qur'an and al-Sunnah of the Messenger of Allah SAW. ${ }^{9}$

The above understanding can be found in the hadith of the Prophet SAW.

"Allah brightens the face of someone who hears one badith from us, then he memorizes it and he tells it to others. Because there are people who bring figh (hadith) delivered to people who are more faqiih (understand) than bim, and there are people who bring fiqh but not faqiih".

This hadith is narrated by Imam Abu Dawud (no. 3660), at-Tirmidhi (no. 2656), Ibn Majah (no. 230), ad-Darimi (no. 229), Ahmad (5/183), Ibn Hibban (no. 680), ath-Thabrani in "al-Mu 'jamul kabiir" (no. 4890), and other priests.

The word fiqih (فق) in language has two meanings. ${ }^{10}$ The first meaning is al-fahmu al-mujarrad (الفهم المجرد), which means to understand directly or just understand. The second meaning is al-fahmu ad-daqiq (الفهم الدقيق), which means to understand or comprehend deeply and more broadly.

As for the term, the word fiqih is defined by the scholars with various different definitions. Some are more piecemeal expressions, but some are indeed already covering all the limitations of the science of fiqih itself.

Al-Imam Abu Hanifah has a unique definition of fiqh, which is:

"Knowing the buman spirit related to what is their rights and obligations".11

Actually this definition is still too general, even still includes the area of faith and faith even including the area of morality. So that the fiqih referred to by him is also referred to as Al-Fikibul Akbar.

As for the definition that further covers the scope of the term of fiqih known to the scholars is: ${ }^{12}$

${ }^{9}$ Ahmad Sarwat, Fiqih \& Syariah. DU Center. Lihat juga hadis Rasulullah saw. "Allah brightens the face of someone who hears one hadith from us, then he memorizes it and he tells it to others.

${ }^{10}$ Ahmad Sarwat, Seri Fiqih Kebidupan (1): Ilmu Fiqibal. Jakarta: DU Publishing, p. 25.

${ }^{11}$ Ubaidillah bin Mas "eud Al-Mahbubi Al-Bukhari Al-Hanafi, At-Taudbihala At-Tanqih, jilid 1. p. 10 
"A Knowledge that discusses the laws of Shari'a in the field of amaliyah (the real deeds) taken from the propositions in detail,"

To understand fiqih and its relation to pluralism, we must refer to the definition of pluralism itself. In etymology pluralism is an absorption word from English which consists of two words. Namely, plural which means variety and ism which means understanding. ${ }^{13}$ So pluralism can be interpreted as a variety of understandings. The terminology pluralism is a framework of interaction in which each group displays respect and tolerance with each other, interacting without conflict or assimilation. In other words pluralism is a theory which says that reality consists of many substances.

According to Alwi Shihab, the understanding of pluralism can be summed up into 3, namely: first, pluralism does not merely refer to the reality of pluralism. However, what is meant by pluralism is active involvement in the reality of pluralism. Second, pluralism must be distinguished from cosmopolitanism. In this case cosmopolitanism refers to a reality in which various racial and national groups live side by side in a location. That is, even though a race and nation live side by side but there is no social interaction. Third, the concept of pluralism cannot be equated with relativism. Relativism considers "all religions are the same". Fourth, religious pluralism is not syncretism, that is creating a new religion by combining certain elements or parts of the teachings of several religions to become an integral part of the religion. ${ }^{14}$

From the definition presented by Shihab, it can be concluded that pluralism is not a concept that says all religions are the same. Pluralism must be separated from the understanding of relativism and syncretism, because in reality many people are trapped in the meaning of these terms. Pluralism stands in its own concept and system of thought and cannot be equated with other terms.

In understanding the framework of pro-pluralism, we should mention the definitions of many experts. Syamsul Ma'arif defines pluralism as an attitude of mutual understanding, understanding and respect for differences in order to achieve the harmony between the religious communities. And in interacting with these various religions, religious people are expected to still

12 Adz-Dzarkasyi, Al-Babrul Mubith, jilid 1 p.21.

13 Pius A. P, M. Dahlan, Kamus Ilmiah Popular, Surabaya: Arkola, 1994, Cet. Ke-1, p.604. lihat juga Anton M. Moeliono, Kamus Besar Bahasa Indonesia, Balai Pustaka, Jakarta,1990, p. 691.

${ }_{14}$ Alwi Shihab, Islam Inklusif Menuju Sikap Terbuka, p. 41-42 
IJIERM: Vol. 2 No. 1 Januari - April 2020

have a strong commitment to their respective religions. ${ }^{15}$ Interaction between religious people has occurred in our daily lives, but for social interaction to run well, there must be rules of mutual understanding. Those rules should be considered in the fiqih of pluralism.

To clarify how the relationship between religious communities in the context of pluralism is, Moh. Shofan defines pluralism as an effort to build theological and social normative awareness among religious communities. $\mathrm{He}$ mentioned pluralism as an effort to build not only theological normative awareness but also social awareness, where we live in a pluralistic society in terms of religion, culture, ethnicity, and other various social diversities. Therefore, pluralism is not only a theological concept, but also sociological concepts. ${ }^{16}$

The plurality is a fact of life where everyone must try to arrive at mutual understanding. The basis of religious plurality is unity of purpose and open dialogue. Awareness of religious plurality will give birth to an awareness of the oneness of faith. The unity of faith works in preserving the history of the continuity of God's revelations, which began from the time of Adam AS to Muhammad SAW. ${ }^{17}$ Basically, the Qur'an has established rules about plural societies in which diverse religions live side by side and can accept each other on an ethical basic.

Here it is seen how important it is to look at fiqih critically. Forcing oneself to use the conclusions used by the classical scholars in responding to the present problem is considered an attempt to sacrifice the present for the past. And if that happens, then religion will be accused as a non-contextual doctrine. Religion will be accused as the source of setback, ignorance, injustice and tyranny. Even though, it is not true if we understand the substance of religion in the present context. What is needed now is to restore the universal values such as public benefit, egalitarianism, rationalism, pluralism as fiqih paradigmatic principles so that they are not trapped in the pools of litreralism, fundamentalism, authoritarianism and conservatism. In addition, the deconstruction of religious thought in the future must develop a culture of interpretation that is open and tolerant. Here hermeneutics can be used as a mechanism to uncover "the delayed meaning" in order to restore

15 Syamsul Ma"arif, Pendidikan Pluralisme di Indonesia, Jogjakarta: Logung Pustaka, 2005, p.17

16 Mohal. Shofan, Menegakean Pluralisme: Fundamentalisme-Konservatif di Tubuh Mubammadiyah, Jakarta: LSAF, 2008, p. 87

${ }^{17}$ Mahmoud Ayoub. Dirasah fial-Alaqah al-Masibiyyah al-Islamiyyah, Libanon: Markas al Dirasah al Masihiyyah al-Islamiyyahal. 2001, p. 265. 
the commitment of universal and pluralist revelations. Hermeneutics which is meant is not just a "revelationist" who hangs himself on revelation limited to the text, but is more applied in "functional" hermeneutics, ie the extent to which the text is able to liberate the reality of humanity. Therefore, in sharpening the commitment of tolerance and pluralism of fiqih , hermeneutics is needed that can at least make a very fundamental change in the tradition of classical fiqih. ${ }^{18}$

Therefore, what must be held is an effort to build a "democratic fiqih", "pluralist fiqih" and "fiqih civil society" that is fiqih that does not use religion as a political commodity. Fiqih that encourages democracy, pluralism and egalitarianism as a prerequisite for the formation of a just and civilized society.

\section{The fiqih dilemma of relations between religions}

The dilemma of fiqih paradigm is a historical view and always adorns contemporary religious thought. It also shows the strengths and the weaknesses of fiqih, when they are able to "carry the past to the present. ${ }^{19}$ Or "carrying the Arab tradition into non-Arab traditions" 20 may be the number of prominent scholars in the country who study the yellow books and learn from the Middle East causing their religious views arabis and theocentric.

This issue is indeed quite basic. First, because fiqih was deliberately written in a time when the relationship between Muslims and non-Muslims was not very conducive. Nasir Hamid Abu Zyaid said that the classical books, both the Qur'anic sciences and fiqih were written in an era when Muslims were facing a crusade, so that the strategic efforts were needed to maintain their identity and to restore Islamic epistemology. In the "text" framework. Jurisprudence is the most important part of the struggle of life at that time, so it is very likely if fiqih adjusts to the context of his time.

Secondly, fiqih is written in the internal situation of Muslims which is not so solid, so it is very possible that the rulers use fiqih as a tool to win the hearts of the people, so that the ulama can design fiqih which seems to give

18 Nurcholish Madjid dkk, Fiqih Lintas Agama, Jakarta: Paramadina, 2004 p. 174-175

19 One concrete proof is the availability of classic books, such as the books of Imam Shafi'i, al-Umm, al-Risalah, Imam al-Ghazali, ibya 'Ulum al-Din, Imam Malik, Muwattha' and Imam etc., so that we can read these books easily.

${ }^{20}$ In the NU tradition, the Babtsul Masa'il laznah still adheres to the category of standard books (al-polar al-mu 'tabarah) as the first reference. Most of the books are fiqh books written by scholars from Arabic origin, for example the work of Wabbah Zuhayly, alFikih al-Islamy wa Adillatubu and others. 
IJIERM: Vol. 2 No. 1 Januari - April 2020

attention to Muslims and reject the presence of non- Islam. This perspective can attract Muslims, because of the attitude of non-Muslim nations towards Islam which tends to be hegemonic and colonialistic. In a long period of time, Muslims are in the shackles and grips from the outside, thus forming a weak and defeated sociological-historical. Therefore, campaigns to give priority to non-Muslim communities often color the classical treasures, as reflected in the fiqih of interfaith relations.

Third, the existence of religious symbols which implicitly advocate a hard attitude towards other religions. In many verses, especially when read literally, it will be concluded rigidly. ${ }^{21}$ For example, verse 120 of Surat alBaqarah: and the Jews and Christians will not leave you, so you follow their religion. If this verse is understood literally, then of course it will cause a bad impression of other religions, especially Judaism and Christianity, because it is as if both religions always come to force Muslims to embrace the two religions. Even though the verse was down in terms of changes in the direction of Qibla and, Masjid al-Aqsa Jerusalem to the Masjid al-Haram, Makkah. Judaism and Christianity chose to defend their holy sites.

Beside that, there are still a number of hadiths that have explicitly signaled hatred of other religions. For example the hadith which reads about the prohibition of saying hello to Christianity and taking another direction when passing Christian adherents. This hadith is always studied in Islamic boarding schools as selected hadiths (al-abadits al-mukbtarah) which are memorized and reflected in everyday life. Even though this hadith came down in a certain context, namely war, which happened to be the Prophet Muhammad who met a Christian who had a hatred of Muslims at that time. This hadith can be categorized as a hadith that arises in certain conditions and contexts and cannot be treated generally for all Christians.

Here, it is increasingly illustrated that the fiqih of interfaith relations is a serious problem faced by modern society. The historical and textual claims can be used as a reason by some fiqih scholars to reject the existence of nonMuslims in the Muslim community. Therefore, the complexity is not only at the textual level, but also the historical background and objective conditions of Muslims who often view "other groups" as a threat. There is an assumption, that the decline of Muslims at that time, not only due to internal problems of Muslims themselves, but also problems that are constructed from the outside. Abid al-Jabiri reinforces this view, that when Islam was in

${ }^{21}$ Nurcholish Madjid dkk, Fiqih ..., p. 43-44 
its heyday, the West felt its positive positives. Even the enlightenment of Islam has brought the West to the door to enlightenment. But on the contrary, when the West is at its golden peak, what is impressed is that the West tends to hegemony the Islamic world. ${ }^{22}$

All of dilemma which are taken from the impression of classical fiqh is not to blame or simplify the problem. The wealth of Islamic studies (fiqih) in classical times is suitable in its day and sometimes it is no longer suitable in the present. But what is important to note is that the door to ijtihad is never closed. Relations between religious communities can work well without demeaning other parties to be conveyed in the jurisprudence of pluralism, and in fact the jurisprudence of pluralism is a realistic ideological building that is important to be taken the principle of its benefits.

\section{Towards Fiqih that is sensitive to Pluralism}

To go to the practical order in pluralist social fiqih, it is required a courage in doing deconstruction of fiqh openly. The deconstruction of fiqh means to dismantle and reject all limitations of interpretation or form a standard conclusion. In Islamic thought and construction can be used as an effort to uncover some dimensions of Islamic tradition with the aim of eliminating truth claims in Islamic thought, especially classical Islamic thought, because after all, the thought is built on the foundation of episteme his day.

The idea of deconstruction which is adopted by Islamic thinkers is intended to dichotomically separate the relationship between the dimensions of historicality whose rules are always changing, with the norms of the Koran or Islamic religion, which are appropriate to the time and place. This idea is also intended to melt when it does not destroy religious thought which is considered sacred by Muslims (taqdis al-afkear al-dlniy), including in the field of fiqh which is confined in the trap of authoritarianism in classical clerics to become a new orthodoxy.

In the pluralism fiqih, the contruction that must be built is to understand plurality as a social fact where, each individual and group knows each other and understands one another. The basic of religious plurality is unity of purpose and open dialogue. The awareness of religious plurality will give birth to awareness of the existence of unity of faith. Unity of faith works in preserving the history of the continuity of God's revelations, which began

22 Muhammad Abid al-Jabiri, al-Aql al-Siyasi al-Araby Beirut: Markaz Dirasat alWuhdah al-Arabiyah, Cetakan III, 1995, p. 19. 
IJIERM: Vol. 2 No. 1 Januari - April 2020

from the time of Adam to Muhammad SAW. ${ }^{23}$ Basically, the Qur'an has established rules about plural societies in which various religions live side by side and can accept each other on an ethical basic.

This plurality is a concept that gets a serious attention to be examined in the classical fiqih building, especially relating to majority-minority relations, Muslim and non-Muslim relations. In many cases, jurisprudence still seems to number two non-Muslims. Even when asked, what problems in the fiqih tradition have not yet received a fair solution? Of course, the answer is interfaith fiqih.

This issue is indeed quite basic. First, because fiqih was intentionally written in a time when the relationship between Muslims and non-Muslims were not very conducive. Nasir Hamid Abu Zyaid said that the classical books were written in an era where Muslims were facing a crusade, so that strategic efforts were needed to maintain the identity and restore the epistemology of Islam within a "text" framework. Fiqih is the most important part of the process of life struggle at that time, so it is very likely that jurisprudence adjusts to the context of its time.

Secondly, fiqih is written in the internal situation of Muslims which is not so solid, so it is possible for the rulers to use fiqih as a tool to win the hearts of the people, so that the ulama can design fiqih that seems to give attention to Muslims and reject the presence of non- Islam. This perspective can attract Muslims, because of the attitude of non-Muslim nations towards Islam which tends to be hegemonic and colonialistic.

Thirdly, the existence of religious symbols which implicitly advocates a hard attitude towards other religions. In many verses, especially when read literally, it will be concluded rigidly. ${ }^{24}$ The problems that become the dilemma of interfaith jurisprudence have resulted in unfavorable relations between Muslims and non-Muslims, and at a later stage the fiqih was carried away by the perspective of the Muslim community. There are several concepts in the classical fiqih doctrine that result in cross-religious fiqhism dilametism such as the concept of abl al-drimmah, jizyah, interfaith marriage and inheritance of different religions. 25

${ }^{23}$ MahmoudAyoub, Dirdsahfi al-'Alaqah al-Masibiyyah al-Islamiyyah, Libanon: Markaz al Dirasah al-MasIhiyyah al-Islamiyyah, 2001, p. 265

${ }^{24}$ Nurcholish Madjid dkk, Fiqih ... p. 43 - 44

${ }^{25}$ Especially for the issue of interfaith marriages, it is indeed very controversial and there is no final word in one conclusion, between those who allow and forbid having an equally authoritative argument. Although there are often calls for a ban on interfaith marriages, in practice they are difficult to avoid, especially lately Madina has become 
In this context, it is very evident that there is stuttering of fiqih in seeing other religions. Here we see how important it is to look at fiqih critically. Forcing oneself to use the conclusions used by classical scholars in responding to the present problem is considered an attempt to sacrifice the present for the past. And if that happens, then religion will be accused of being a contextual teaching. Religion will be accused as the source of setback, ignorance, injustice and tyranny.

Yang diperlukan sekarang yaitu mengembalikan nilai-nilaiuniversal seperti kemaslahatan umum, egaliterianisme, rasionalisme,pluralisme sebagai prinsip-prinsip paradigmatik fiqih sehingga tidakterjebak dalam kubangan litreralisme, fundamentalisme, otoritarianismedan konservatisme. Selain itu, dekonstruksi pemikiran keagamaan dimasa datang mesti mengembangkan budaya tafsir yang terbuka dantoleran. Di sini hermeneutika dapat dijadikan mekanisme mengungkap"makna yang tertunda" guna mengembalikan komitmen wahyu yangbersifat universal dan pluralis.. Hermeneutika yang dimaksud tidakhanya sekedar "revelasionis" yang menggantung diri pada wahyu yangterbatas pada teks, akan tetapi lebih diaplikasikan dalam hermeneutika"fungsional", yaitu sejauhmana teks mampu melakukan pembebasanterhadap realitas kemanusiaan.

What is needed now is to restore the universal values such as public benefit, egalitarianism, rationalism, pluralism as the principles of paradigmatic fiqih so that they are not trapped in the pools of literalism, fundamentalism, authoritarianism and conservatism. In addition, the deconstruction of religious thought in the future must develop a culture of interpretation that is open and tolerant. Here, the hermeneutics can be used as a mechanism to uncover "pending meanings" in order to restore the commitment of universal and pluralistic revelations. The hermeneutics referred to is not merely "revisionation" that hangs itself to revelation limited to the text, but is more applied to hermeneutics "functional", namely: how far the text is able to liberate the reality of humanity.

Therefore, in sharpening the commitment of tolerance and pluralism of fiqih, the hermeneutics is needed which at least can make a very fundamental change in the tradition of classical fiqih. First, believing the text as a cultural product. Text and culture are two inseparable coins. When talking about the text, it actually speaks of culture, and vice versa. Therefore it is necessary to deconstruct theological beliefs from existentiality as God's revelations, to

facilitators of interfaith marriages, a new breakthrough in Islamic fiqih discourse in Indonesia. The pros and cons response accompanied this breakthrough. 
IJIERM: Vol. 2 No. 1 Januari - April 2020

revelations formed and perfected by culture. Second, believing the text as progressive revelation so that it does not become ideological and used as a means of justification of political power. If there is a conflict between a text and a human problem, then the text itself cannot be used. Third, believing in an emancipatory paradigm that is in line with the revelation commitments, such as the Koran as open text, equality, humanity, pluralism, liberation, equality, gender justice, non-discrimination.

Therefore, what must be held is an effort to build "democratic fiqih", pluralist fiqih and "fiqih of civil society" ie jurisprudence that does not use religion as a political commodity. Fiqih which encourages democracy, pluralism and egalitarianism as a prerequisite for the formation of a just and civilized society.

\section{CONCLUSION}

Legitimacy and acknowledgment of the existence of universal similarities between one religion and another especially the three major religions (Judaism, Christianity and Islam) are not enough to build and develop harmony between religions, because religions often face each other in tense situations, contradictory, confrontational and even prolonged conflicts that lead to misery and disaster, as shown by many facts in various places, especially Islam versus Christianity in the country (Lombok, Poso, Ambon). Of course, religion is not the only contributor to social tensions or conflicts, because human life is multi-dimensional that involves various aspects of life such as economics, politics, social culture, security. Here lies one of the reasons for the need to hold relations between religious groups at the praxis level, namely dialogue and cooperation. Dialogue and cooperation are two things that continue to connect. One presupposes the other. There is no collaboration without being preceded by a dialogue. And dialogue that does not continue with collaboration is half-hearted dialogue, even verbalism (in the sense of saying something that feels like it did).

In the globalization era nowadays, people must be willing to live in a pluralistic social environment, transcending ethnic, cultural and religious boundaries. To organize a harmonious life, we are required to be able to face the reality of diversity tyluralism). The concept of pluralism has become a philosophy of state governance in the world today. The spirit and concept of pluralism can be explicitly found in the primary sources of Islamic doctrine namely the Qur'an and al-Hadith. In Islam, pluralism is the basic of the nature creation and hence pluralism does not have the potential to cause conflict, but rather has the potential to form an equilibrium. 


\section{REFERENCE}

Adz-Dzarkasyi, Al-Babrul Mubith, jilid 1

Al-Hanafi, Ubaidillah bin Mas"ud Al-Mahbubi Al-Bukhari. At-Taudhib ,ala AtTanqih, jilid 1

al-Jabiri, Muhammad Abid. al-Aql al-Siyasi al-Araby (Beirut: Markaz Dirasat alWuhdah al-Arabiyah, Cetakan III, 1995)

Ayoub, Mahmoud. Dirdsabfi al-'Alaqah al-Masibiyyah al-Islamiyyah (Libanon: Markaz al Dirasah al-MasIhiyyah al-Islamiyyah, 2001)

Ayoub, Mahmoud. Dirasah fial-Alaqah al-Masibiyyah al-Islamiyyah (Libanon: Markas al Dirasah al Masihiyyah al-Islamiyyahal. 2001)

Fatwa MUI in Media Dakwah Magazine No. 358 Ed. Sya'ban 1426H/September 2005

Hornby, A.S. et.al., The Advanced Learner's Dictionary of Current English (Oxfort : Oxford UniversityPress, 1972)

Husaini, Adian. Islam Liberal Paska Fatwa MUI, dalam majalah Media Dakwah, Edisi No. 358 Sya'ban 1426 H-September 2005.

Ka'bah, Riyal. Nilai-nilai Pluralisme Dalam Islam: Bingkai Gagasan yang Berserak, (Ed.) Suruin, (Bandung: Penerbit Nuansa, 2005)

Ma"arif, Syamsul. PendidikanPluralismedi Indonesia, (Jogjakarta: Logung Pustaka, 2005)

Madjid, Nurcholish. dkk, Fiqih Lintas Agama, (Jakarta: Paramadina, 2004)

Moeliono, Anton M. Kamus Besar Bahasa Indonesia, Balai Pustaka, Jakarta,1990

Pius ,A. P, and M. Dahlan. Kamus Ilmiah Popular, (Surabaya: Arkola, 1994), Cet. Ke-1,

Saifuddin, Upaya Mempertemukan Realitas dalam Pluralitas Sosial Budaya, Jurnal Suhuf, No.01 Tahun XII, 2000

Sarwat, Ahmad. Seri Fiqih Kehidupan (1): Ilmu Fiqihal. (Jakarta: DU Publishing, T'T)

Shofan, Mohal. Menegakean Pluralisme: Fundamentalisme-Konservatif di Tubuh Muhammadiyah, (Jakarta: LSAF, 2008)

Suseno, Frans Magnis. Menjadi Saksi Kristus di Tengah Masyarakat Majemuk", Jakarta: Obor, 2004

Thoha, Anis Malik. Tren Pluralisme Agama, Tinjauan Kritis, Jakarta: Perspektif, 2005 